\title{
Parameters that influence the chromatic variation of porous face ceramic waterproofed with organosilicic products
}

\section{Parámetros que influyen en la variación cromática de la cerámica porosa cara vista hidrofugada con productos organosilícicos}

Jesús Ángel Coronado Martín (Main and Corresponding Author)

Carrera de Artes Plásticas, Facultad de Educación, Ciencia y Tecnología (FECYT)

Universidad Técnica del Norte (Ecuador)

Avenida 17 de julio, 5-21, CP 100105, Ibarra

jcoronado@utn.edu.ec

\section{Alfonso García Santos}

Departamento de Construcción y Tecnología Arquitectónicas. Escuela Técnica Superior de Arquitectura Universidad Politécnica de Madrid (Spain)

Av. Juan de Herrera, 4, 28040 Madrid

alfonso.garciasantos@upm.es

Manuscript Code: 716

Date of Acceptance/Reception: 06.04.2017/02.12.15

DOI: $10.7764 /$ RDLC.16.2.295

\begin{abstract}
All water repellent products, theoretically colorless, when applied superficially in the porous face ceramic, produce a chromatic variation in the color of the ceramic. The factors that influence the color variation are explored. The ceramic is selected according to its type of manufacture: manual, pressed and extruded, characterizing it considering the absorption coefficient, open porosity, absorption rate, surface finishing and initial color parameters. The water repellent products are selected on the basis of their chemical composition. The final color of the waterproofing ceramics is analysed together with the parameters obtained from the characterization of the ceramic, noting that the only color variation depends on the initial color of the ceramic, existing a linear relationship between the initial and final color of the waterproofing ceramics with each of the products. The final color of a ceramic can be predicted, depending on the composition of the water repellent product being applied.
\end{abstract}

Key words: Porous ceramic face, surface properties, chromatic variation, water repellents, color space RGB.

\section{Resumen}

Todos los productos hidrofugantes, teóricamente incoloros, al aplicarlos superficialmente en la cerámica porosa cara vista, producen variación cromática del color de la cerámica. Se estudian los factores de los que depende dicha variación de color. La cerámica se selecciona en función de su tipo de fabricación: manual, prensada y extrusionada, caracterizándola en función de los parámetros del coeficiente de absorción, porosidad abierta, acabado superficial, tasa de absorción y color inicial. Los productos hidrofugantes se seleccionan en función de su composición química. Se relaciona el color final de la cerámica hidrofugada con los parámetros obtenidos de la caracterización de la cerámica, observando que la variación cromática solo depende del color inicial de la cerámica, existiendo una relación lineal entre el color inicial y final de la cerámica hidrofugada con cada uno de los productos. Se puede predecir el color final de una cerámica, dependiendo de la composición del producto hidrofugante aplicado.

The most frequent failures are produced due to the humidity originated from the rain water that infiltrates through the roof and façade, as well for water penetration from the land surrounding the basement wall and ground floors through ascending absorption due to the phenomenon known as capillarity. The dampness caused by the rain water that infiltrates through the facade is one of the main causes of pathologies in buildings (Chávez \& Álvarez, 2005).

Interventions in architectural heritage are intended to curb the deterioration of materials and propose solutions of conservation so that materials could withstand the alteration processes over a reasonable period of time (Heathcote, 1995). The stone and ceramic materials are protected with the use of consolidating and/or water repellent products. Water repellents repel the water that contacts the surface of the base material protecting it from the entrance of this, in addition to the action of atmospheric pollution (Esbert \& Sánchez, 1995). The treatment with water repellents acts forming a continuous film that covers the surface of the capillary pores of the ceramic material, decreasing the suction of water without clogging the pores (Fort et al., 2012). 
The water repellents are an impregnation, theoretically colorless, that penetrates through the porosity of the material on which it is applied. The adhesion between an impregnation and ceramics is due to several factors, but mainly due to the difference in surface tensions existing between the two materials (Pérez-Monserrat, Gómez-Heras, Álvarez de Buergo, \& Fort, 2007). The composition of the water-repellents is based on the use of polymeric materials that have a lower surface tension than the rest of the materials used in construction and in this way, their stickiness is guaranteed (García, 2001).

There are investigations that study the waterproofing treatments applied to different supports. Fortes \& BlancoVarela (2001) analyzed the influence of these products applied on lime and lime and pozzolana mortars. Tsakalof, Manoudis, Karapanagiotis, Chryssoulakis, \& Panayiotou (2007) study the water-repellent efficacy based on siloxane, perfluoro and fluoro-organosilane applied on different stones such as marble, travertine, sandstone and brick. Rivas, Silva, \& Prieto (1998) analyzed the durability of two waterproofing treatments applied to granitic rocks and in another research analyzed the effectiveness of consolidating and waterproofing treatments applied to granitic rocks (Silva, Rivas, \& Prieto, 2000).

Water repellent products must ensure sufficient penetration, prevent water ingress, but be permeable to water vapor to "breathe" and require it not to change the color or appearance of the material on which it is applied (Amoroso \& Fassina, 1985). Alvarez de Buergo \& Fort (2002) study the penetration of water-repellant treatments in limestone, obtaining values between 1 and $20 \mu \mathrm{m}$ depending on the product and the porosity of the stone, indicating in another study that the penetration depends on the nature of the stone and pore volume (Alvarez de Buergo \& Fort, 2001). In the case of water repellents applied on ceramic, Coronado (2012) limits the penetration values between 3.5 and $6 \mu \mathrm{m}$, depending on the type of water repellent applied and the type of manufacture of the ceramics (manual, pressed or extruded).

Cultrone, Cazalla, Rodríguez, De la Torre, \& Sebastián (2005) studied the use of colorimetry as non-destructive technique to detect pathologies in heritage conservation. The variation of certain parameters related to the color of a material, may indicate the existence of any pathology, as well as a changing aesthetics, sort of important.

In most cases, when water repellent products are applied, there is no appreciable variation in the color of the treated porous ceramic, but over time, depending on the composition of the product, as well as the exposure to radiation, the material may appreciably modify its chromaticity and luminosity (García, Sánchez de Rojas, \& Frías, 1999). There are studies on the porous ceramics face that indicate that there is color variation when applying water repellent, theoretically colorless, depending such variation on the product applied (Coronado \& García, 2011).

The parameters that influence on the chromatic variation occurred in the porous face ceramic to be treated superficially with water repellents, theoretically colorless, are not known and, therefore, must be studied. The objective of this article is to carry out this study, that is why, 12 models of ceramic are selected, that are characterized by obtaining its initial parameters: absorption coefficient (CA), open porosity $(\beta)$, rate of absorption (C), surface finishing and initial color, and subsequently it is waterproofed with the different selected products, obtaining the final color of the treated ceramic. The final color obtained is related with the initial parameters of the characterized ceramic to study the parameters that influence in the chromatic variation of the waterproofed ceramic with each product.

The color space RGB is used for the quantification of the color, based on the primary colors red (R), green (G) and blue (B), performing the digital measurement of the color by using the image histograms. Akhan Baykan, Yilmaz, \& Kansun (2010) claim that the RGB color space is recommended, as compared to other color spaces (CIELab and HSV), for the identification of minerals and Coronado (2012) shows that it is a space of valid color to get quantifications of color in relative value with respect to a base measurement, thus generating a very fast tool to use in order to establish a systematic approach used for the quantification of chromatic variations in ceramic materials.

There are investigations in which this model is applied to study chromatic variations of building materials by applying different surface treatments: antigraffiti on cement mortar (Sarabia \& García, 2015), antigraffiti on ceramics (García \& Conci, 2005) and to identify the water repellent that produces less chromatic variation in porous face ceramic (Coronado \& García, 2014). 


\section{Porous face ceramic}

The selection of the porous face ceramic is performed depending on its type of manufacture: manual (ceramics $1,2,3$ and 4), pressed (ceramics 5, 10, 11 and 12) and extruded (ceramics 6, 7, 8 and 9), choosing 12 models of ceramic in brick shape, so that all the porous face ceramics that currently exist in the market are represented.

\section{Water repellent products}

Pérez-Monserrat et al. (2007) structures the water repellent products in two large groups: organic and organ-silicic. The studied for this research are the body-silicic, as they are currently the most widely used for application on porous face ceramic materials, classifying them in: mono-component and bi-component. Coronado (2012) performs the selection of the water repellent products depending on its composition. The mono-component are: product $\mathrm{H} 1 \mathrm{of}$ silicone components, H2 silanes, H3 siloxanes oligomeric, globules, H4 polymer siloxanes and H5 fluoridated resin. The $\mathrm{H} 6$ product is composition silanes/siloxanes, classified as bi-component.

Methodology

The methodology used for this research is divided into two parts:

- Characterization of the porous face ceramic getting the following parameters: absorption coefficient (CA), open porosity $(\beta)$, rate of absorption (C) and surface finishing.

- $\quad$ Colorimetric Assay: getting the parameters of the initial color and end of the ceramic.

All tests are performed on the face of the ceramic, except obtaining the absorption coefficient (AC) and the open porosity $(\beta)$ which, according to the regulations, has to be made with complete pieces, being the results of both parameters translatable to all faces of the ceramics tested.

\section{Characterization of the ceramics}

The absorption coefficient and open porosity of the ceramic without waterproofing, are obtained on the basis of the normative UNE 67,027-84 and UNE-EN 772-4:1999 that are aimed at the determination of the water absorption and of the open porosity in bricks used in construction (specified in standard UNE 67.019). To get the initial absorption rate, the test is performed based on the standard UNE-EN 772-11:2001 which aims at the determination of the absorption coefficient by capillarity pieces of ceramic and the water absorption rate on the face in the pieces of baked clay for the ceramics.

The absorption coefficient (CA) is the percent of water absorbed by the specimen in the test, expressed in relation to the mass of the dried brick. The open porosity $(\beta)$ is also known as accessible or communicated porosity, and it is defined as the volume of open pores or communicated among themselves and with the exterior (accessible to the water normally) per unit of total volume. For obtaining both parameters six ceramics of each selected model are tested.

To get the absorption coefficient and the open porosity it is used the following instruments: vented oven capable of maintaining a temperature of $100{ }^{\circ} \mathrm{C} \pm 5{ }^{\circ} \mathrm{C}$, electronic scales: to weigh out the test specimens, with a sensitivity of 0.5 $\mathrm{g}$ and immersion tank with necessary measures to allow the full introduction of the ceramic.

The test specimens are dried up in the oven at $100 \stackrel{\circ}{\circ}$, weighing after the 21 and 24 hours of drying. If the weight difference is less than $0.1 \%$ are dried. If not, it remains draining until the difference between weighing is less than 0.1 $\%$. The minimum interval among weighing will be three hours, being the last weighing the dry mass MSU. After cooled they are introduced in the tank, so that their full immersion is achieved in a minimum time of three hours. Within 24 hours after the immersion has started, each test specimen is taken out of the water and each one is weighed being immersed in the water, introducing it again in water. Weighing continues every 24 hours until two consecutive weighing from less than $0.1 \%$. The last weighing is the submerged mass MWU.

After the previous weighing, the test specimen is pulled out from the water, it is dried with a damp cloth and weighed to get the saturated mass Mau. This weighing is the weight after absorption Mau. The water absorbed is Mau-Msu (all weighings are made with an error $<0.05 \%)$. 
The absorption coefficient $(\mathrm{CA})$ of each ceramic tested is obtained according to the expression: $\mathrm{CA}(\%)=(\mathrm{Mau}-$ $\mathrm{Msu}) / \mathrm{Msu} \times 100$. The resulting absorption coefficient will be the arithmetic mean of the six ceramics results.

The open porosity $(\boldsymbol{\beta})$ is obtained according to the expression $\beta(\%)=V P A / U N V \times 100$, being the Vpa volume of open pores, calculated by the equation $\mathrm{Vpa}=(\mathrm{Mau}-\mathrm{Msu}) / \rho$ and $\mathrm{Vnu}$ the net volume, which is obtained as follows: $\mathrm{Vnu}=(\mathrm{Mau}-\mathrm{Mwu}) / \rho$. The open porosity result will be the arithmetic mean of the results of the six ceramics of each model tested.

The rate of absorption $(\mathbf{C})$ is the ability of a material, which is found in superficial contact with the water, to absorb it by capillarity. The face is brought into contact with the water which passes through the porous network, being the total penetration and the speed of the process dependent on the nature of the material and geometry, and roughness of the capillary network. It is measured in $\mathrm{Kg} / \mathrm{m}^{2} \mathrm{x}$ min.

To obtain it the following tools are required: electronic balance with an accuracy of $0.1 \%$ of its mass in the dry state, bowl with minimum depth of $50 \mathrm{~mm}$ and device to keep the water at a constant level, support of $400 \mathrm{~mm} 2 \mathrm{of}$ maximum surface area to keep the test piece above the bowl and a stopwatch.

Once they are dried, its tested face is introduced into the bucket, previously filled with water up to the indicated level. The test specimens are placed on the bracket so that they do not touch the bottom of the container and they are submerged a depth of $5 \mathrm{~mm} \pm 1 \mathrm{~mm}$ throughout the test. When the test specimens are deepen into the water, the stopwatch starts and it is held in the bowl 1 minute, then it is pulled out and weighed.

The total weight of the test specimen is gotten in environmental temperature plus the weight of the sucked water. Therefore, the weight gain experience by the test specimen is calculated based on the time. The absorption rate is calculated (C), to obtain the absorption rate (UNE-772-11:2001) the following formula is used: $\mathrm{C}=(\mathrm{Mi}-\mathrm{Ma}) / \mathrm{As} \times \mathrm{t}$, where $\mathrm{C}$ is the absorption rate $\left(\mathrm{Kg} / \mathrm{m}^{2} \mathrm{x} \mathrm{min}\right)$; Mi: mass of the test specimen after immersion ( $\left.\mathrm{Kg}\right)$; Ma: mass of the test specimen at ambient temperature (Kg); As: gross surface area of the submerged face $\left(\mathrm{m}^{2}\right)$ and $\mathrm{t}$ : time (one minute).

Surface finishing: four characteristics define the surface finish: roughness (small deviations from the nominal surface line), waviness (deviations of much greater spacing), orientation (predominant direction) and defects or faults (occasional irregularities such as cracks, scratches, craters, etc.). Ceramics are classified according to their surface finishing in smooth and rough as the manufacturers indicate in their datasheets. The smooth ceramics do not have appreciable discontinuities on the surface to the naked eye. The rough ceramics have discontinuities whether roughness, waviness, orientation and/or defects. Besides what is indicated on the datasheets of each ceramic, visual and tactile checks are made to classify them as smooth or rough. Figure 1 shows examples of the finishes of two ceramics, one rough and one smooth.

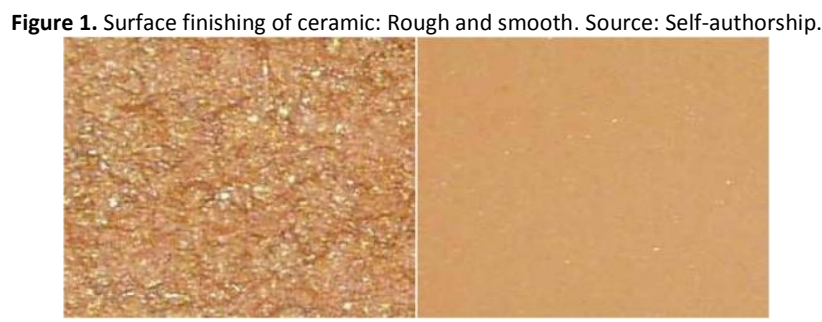

\section{Colorimetric Assay}

The parameters of the initial and final color of the ceramics is obtained with this test. In each model of ceramics, half of the facade is waterproofed leaving the other half without testing. The waterproofing is performed by brush until saturation of the bracket, according to the manufacturer's recommendations (Wacker-chemie, 1973). The drying time of the waterproofed samples is a minimum of 24 hours (the recommended time by the manufacturers so that the water repellent get completely dry). Both the waterproofing of samples and the drying, are carried out in laboratory environmental conditions (laboratory ambient temperature $20 \circ \mathrm{C}$ with $\pm 2{ }^{\circ} \mathrm{C}$ and relative humidity $35 \%$ ).

Data collection is based on previously published work (Coronado \& García, 2011; Coronado, 2012; Coronado, García, \& Padial, 2013; Coronado \& García, 2014). A Olimpus 400 digital camera of 4.0 megapixel placed in a table of photo reproduction is used. The target of the camera is positioned at a distance of $40 \mathrm{~cm}$ from the face ceramic. The ceramic illuminates with 4 bulbs of 75 watts, getting in the base of photo reproduction table, an illuminance value of 760 lux, 
measured with digital luxmeter of the brand koban, model kl-6610. The bulbs are placed in such a way that no shadows are generated on the ceramic face.

Coronado (2012) indicates that the collection of data is performed between 24 and 72 hours after the waterproofing of samples. The ceramics is placed on the table of photo reproduction, facing the facade towards the camera and this is shoot by remote control. The result is an image where the sample submitted is fully observed, original image. Through a computer software PhotoShop CS6 a central part of the waterproofing area is clipped and a central zone of the non-waterproofing zone, being these last images the ones analyzed.

The images obtained are analyzed in the RGB color space using the image histograms that consist of a bar graph of 256 columns representing the number of pixels in the image for each lightness value from black (0) to white (255). On the horizontal axis, the different shadings divided into 256 columns, from black (left) to white (right) are placed. The height of each of the columns determines the number of pixels for each of the lightness values, indicating the average (average value of luminosity of the set of pixels). The images for both the untreated areas (initial color) as water repellent (final color) are analyzed by the image histogram, obtaining quantifiable data of luminosity, red, green, and blue. Image histograms, by measuring RGB color space, give values of the three primary colors in this space (red, green and blue) and also give us the value of the luminosity which is the amount of light reflected by a surface in comparison with that reflected by a white surface in the same lighting conditions, quantifying its value between 0 and 255. The brightness describes how light or dark a color looks, and refers to the amount of light reflected by a surface.

The data collection of each one of the ceramics consists of six photos, each one is analyzed, obtained from them, their respective histogram values, being the representative value the arithmetic mean of the values obtained from luminosity, red green and blue, in each picture (Coronado, 2012).

The initial ceramic color as the arithmetic mean of the six photographs is gotten, from each of the values of histogram and luminosity, of the area of ceramics without treating. The data obtained from the initial color and final color of the ceramics 6 treated with the $\mathrm{H} 6$ silanes/siloxanes are shown in Figure 2.



According to their initial color, the ceramic material is classified in five colors: white, gray, ochre, red and brown, depending on their values of histogram in the RGB color space (Coronado, 2012). The ranges of values for color and luminosity of each color are the following:

White: luminosity: 198-220; R: 221-232; G: 210-220; B: 167-190.

Gray: luminosity: 162-222; R: 182-232; G: 166-221; B: 136-196.

Ochre: luminosity: 148-204; R: 215-231; G: 186-203; B: 112-145.

Red: luminosity: 140-195; R: 204-229; G: 126-188; B: 54-108.

Brown: luminosity: 129-185; R: 163-209; G: 124-180; B: 49-139.

The final color of the waterproofed ceramic with each of the products, is obtained as the arithmetic average of the six photographs, of each histogram and luminosity value of the waterproofed ceramic area. 
After the tests for the characterization of the ceramics Table 1 shows the results reflecting the parameters of the coefficient absorption (CA), open porosity ( $\beta$ ), absorption rate (C) and surface finishing and the initial color reflecting its primary values $R, G, B$ and the brightness value.

Table 1. Results obtained from the absorption coefficient (CA), open porosity ( $\beta$ ), rate of absorption (C), and surface finishing the initial color of the ceramic.

\begin{tabular}{|c|c|c|c|c|c|c|c|c|c|}
\hline \multirow[b]{2}{*}{ Ceramic } & \multirow{2}{*}{$\begin{array}{c}\text { Absorption } \\
\text { Coef. } \\
\text { (CA) (\%) }\end{array}$} & \multirow{2}{*}{$\begin{array}{l}\text { Open } \\
\text { Porosity } \\
(\beta)(\%)\end{array}$} & \multirow{2}{*}{$\begin{array}{c}\text { Absorption } \\
\text { Rate }(\mathrm{C}) \\
\left.\text { (g/m } \mathrm{m}^{2} \times \mathrm{min}\right)\end{array}$} & \multirow{2}{*}{$\begin{array}{l}\text { Surface } \\
\text { Finising }\end{array}$} & \multicolumn{4}{|c|}{ Initial color } & \multirow[b]{2}{*}{ Color } \\
\hline & & & & & Luminosity & Red & Green & Blue & \\
\hline Ceramic 1 & 16.67 & 29.32 & 2357.6 & Rought & 182.02 & 208.41 & 178.43 & 108.76 & Brown \\
\hline Ceramic 2 & 20.08 & 33.30 & 2940.6 & Rought & 202.74 & 230.14 & 200.51 & 135.22 & Ochre \\
\hline Ceramic 3 & 20.51 & 34.18 & 3214.8 & Rought & 209.58 & 226.03 & 210.23 & 172.97 & White \\
\hline Ceramic 4 & 21.49 & 33.47 & 3382.0 & Rought & 203.47 & 225.00 & 202.63 & 137.89 & Ochre \\
\hline Ceramic 5 & 7.43 & 15.72 & 986.3 & Smooth & 219.75 & 231.26 & 219.06 & 186.92 & White \\
\hline Ceramic 6 & 12.47 & & 344.5 & & & 226.83 & & 10 & Red \\
\hline Ceramic 7 & 15.65 & 29.07 & 1070.3 & Rought & 212.96 & 230.50 & 212.47 & 168.82 & Gray \\
\hline Ceramic 8 & 12.08 & 22.03 & 465.5 & Smooth & 177.49 & 209.03 & 176.12 & 99.83 & Red \\
\hline Ceramic 9 & 15.48 & 27.46 & 1722.1 & Rought & 136.81 & 183.75 & 124.81 & 74.25 & Brown \\
\hline Ceramic 10 & 6.23 & 13.06 & 267.5 & Smooth & 149.69 & 198.86 & 137.76 & 80.72 & Brown \\
\hline Ceramic 11 & 6.25 & 12.55 & 384.3 & Smooth & 214.36 & 222.49 & 216.18 & 183.87 & White \\
\hline Ceramic 12 & 5.42 & 11.35 & 399.8 & Smooth & 129.16 & 165.53 & 125.70 & 49.96 & Brown \\
\hline
\end{tabular}

Source: Self-authorship.

The results of the absorption rate (C) of the waterproofed ceramics with each product are shown in Table 2.

\begin{tabular}{|c|c|c|c|c|c|c|}
\hline \multirow[b]{2}{*}{ Ceramic } & \multicolumn{6}{|c|}{ Absorption rate $(\mathrm{C})$ Waterproofed ceramic $\left(\mathrm{g} / \mathrm{m}^{2} \times \mathrm{min}\right)$} \\
\hline & $\begin{array}{c}\mathrm{H} 1 \\
\text { Siliconates }\end{array}$ & $\mathrm{H} 2$ Silanes & $\begin{array}{c}\mathrm{H} 3 \\
\text { Oligomeric } \\
\text { Siloxanes } \\
\end{array}$ & $\begin{array}{c}\mathrm{H} 4 \\
\text { Polymeric } \\
\text { Siloxanes } \\
\end{array}$ & $\begin{array}{c}\mathrm{H} 5 \\
\text { Fluorinated } \\
\text { Resin } \\
\end{array}$ & $\begin{array}{c}\text { H6 } \\
\text { Silanes/Siloxanes }\end{array}$ \\
\hline Ceramic 1 & 221.2 & 72.6 & 88.5 & 54.5 & 146.7 & 39.2 \\
\hline Ceramic 2 & 65.4 & 54.8 & 74.4 & 41.8 & 84.5 & 27.4 \\
\hline Ceramic 3 & 91.4 & 87.3 & 82.2 & 118.1 & 437.5 & 100.1 \\
\hline Ceramic 4 & 40.6 & 64.9 & 757.5 & 91.9 & 97.4 & 75.7 \\
\hline Ceramic 5 & 17.8 & 100.1 & 84.9 & 47.9 & 64.2 & 83.1 \\
\hline Ceramic 6 & 19.6 & 28.7 & 43.0 & 45.7 & 35.3 & 32.1 \\
\hline Ceramic 7 & 79.3 & 51.4 & 224.6 & 73.4 & 115.9 & 88.1 \\
\hline Ceramic 8 & 32.1 & 79.5 & 71.0 & 30.8 & 53.4 & 64.3 \\
\hline Ceramic 9 & 93.8 & 108.1 & 99.8 & 12.8 & 138.5 & 93.4 \\
\hline Ceramic 10 & 5.2 & 48.1 & 77.7 & 24.5 & 76.7 & 56.3 \\
\hline Ceramic 11 & 5.1 & 128.1 & 77.6 & 49.2 & 59.5 & 37.5 \\
\hline Ceramic 12 & 1.7 & 36.8 & 54.5 & 46.4 & 39.9 & 51.7 \\
\hline
\end{tabular}

Source: Self-authorship.

Table 3 shows the results of the final color of the waterproofed ceramic with each of the water repellent products, according to their values of histogram: luminosity, red, green, and blue. 
Table 3. Final Color of the ceramic applied according to the water repellent products.

\begin{tabular}{|c|c|c|c|c|c|c|c|c|c|c|c|c|}
\hline \multirow{2}{*}{ Ceramic } & \multicolumn{4}{|c|}{ H1 Siliconates } & \multicolumn{4}{|c|}{ H2 Silanes } & \multicolumn{4}{|c|}{ H3 Oligomeric Siloxanes } \\
\hline & Lumin. & Red & Green & Blue & Lumin. & Red & Green & Blue & Lumin. & Red & Green & Blue \\
\hline Ceramic 1 & 175.7 & 204.4 & 175.1 & 101.7 & 174.2 & 203.2 & 173.7 & 98.1 & 174.2 & 204.5 & 173.4 & 96.3 \\
\hline Ceramic 2 & 194.8 & 228.5 & 191.5 & 121.5 & 3.5 & 224.0 & 192.0 & 119.5 & 195.3 & 227.1 & 192.9 & 121.6 \\
\hline Ceramic 3 & 211.9 & 228.6 & 210.8 & 173.1 & 3.9 & 230.9 & 212.7 & 3 & .6 & 227.2 & .2 & 169.9 \\
\hline Ceran & 187.4 & 211.8 & 187.1 & 123.6 & .8 & 220.8 & 197.8 & 135.3 & 194.3 & 217.2 & 195.1 & 128.5 \\
\hline Ceramic 5 & 3 & 225.8 & & & & & & & & & & \\
\hline Ceramic 6 & 180.1 & 223.2 & 174.8 & 92.1 & 176.3 & 221.3 & 171.0 & 82.9 & 179.1 & 221.9 & 174.3 & 90.3 \\
\hline Ceramic 7 & 201.6 & 222.1 & 201.6 & 146.4 & 208.0 & 222.8 & 208.2 & 167.1 & 201.6 & 219.2 & 201.3 & 146.4 \\
\hline Ceramic 8 & 171.4 & 206.0 & 169.9 & 85.9 & 170.1 & 204.9 & 168.5 & 85.0 & 167.7 & 202.7 & 165.4 & 85.0 \\
\hline Ceramic 9 & 151.9 & 202.4 & 138.5 & 87.3 & 139.0 & 189.7 & 125.8 & 72.8 & 138.3 & 182.7 & 127.0 & 78.8 \\
\hline Ceramic 10 & 149.6 & 200.4 & 137.2 & 78.9 & 151.0 & 200.9 & 138.8 & 81.7 & 140.6 & 193.9 & 127.4 & 67.2 \\
\hline Ceramic 11 & 209.5 & 216.9 & 211.7 & 178.4 & 207.2 & 215.1 & 209.5 & 174.2 & 207.5 & 215.5 & 209.6 & 174.6 \\
\hline Ceramic 12 & 142.4 & 182.3 & 137.2 & 62.2 & 139.5 & 178.7 & 134.5 & 60.6 & 126.5 & 164.9 & 122.0 & 46.6 \\
\hline
\end{tabular}

\begin{tabular}{lcccccccccccc}
\hline \multirow{2}{*}{ Ceramic } & \multicolumn{3}{c}{ H4 Polymeric Siloxanes } & \multicolumn{3}{c}{ H5 Fluorinated Resin } & \multicolumn{3}{c}{ H6 Silanes/Siloxanes } \\
\cline { 2 - 13 } & Lumin. & Red & Green & Blue & Lumin. & Red & Green & Blue & Lumin. & Red & Green & Blue \\
\hline Ceramic 1 & 173.8 & 205.3 & 172.9 & 93.7 & 169.0 & 202.7 & 167.7 & 84.6 & 146.0 & 191.3 & 141.6 & 46.2 \\
Ceramic 2 & 193.1 & 224.9 & 191.3 & 116.4 & 189.9 & 224.8 & 187.7 & 107.4 & 184.8 & 223.3 & 182.8 & 91.5 \\
Ceramic 3 & 214.2 & 230.3 & 213.3 & 176.1 & 207.1 & 227.1 & 206.2 & 158.6 & 206.4 & 227.1 & 205.3 & 157.0 \\
Ceramic 4 & 194.0 & 216.0 & 194.4 & 132.5 & 185.7 & 211.0 & 186.3 & 114.0 & 184.6 & 212.5 & 186.6 & 98.3 \\
Ceramic 5 & 209.1 & 223.9 & 209.4 & 167.9 & 214.3 & 227.4 & 214.6 & 178.4 & 207.8 & 222.9 & 208.2 & 164.4 \\
Ceramic 6 & 174.4 & 220.0 & 168.2 & 83.9 & 178.0 & 223.3 & 173.2 & 81.2 & 170.2 & 222.9 & 165.3 & 52.5 \\
Ceramic 7 & 193.7 & 218.4 & 193.1 & 130.6 & 198.6 & 219.8 & 198.8 & 139.9 & 198.1 & 220.6 & 198.5 & 135.5 \\
Ceramic 8 & 170.6 & 204.9 & 169.0 & 86.2 & 172.7 & 206.8 & 142.9 & 87.4 & 170.4 & 206.6 & 169.8 & 76.2 \\
Ceramic 9 & 143.5 & 186.3 & 133.0 & 84.0 & 137.1 & 192.8 & 122.6 & 64.1 & 138.0 & 197.0 & 123.2 & 57.9 \\
Ceramic 10 & 141.4 & 193.4 & 128.5 & 70.3 & 136.1 & 193.6 & 122.2 & 55.2 & 131.1 & 195.6 & 116.0 & 37.7 \\
Ceramic 11 & 210.0 & 217.9 & 212.2 & 177.6 & 210.3 & 218.3 & 212.5 & 177.5 & 209.6 & 217.8 & 211.7 & 176.7 \\
Ceramic 12 & 131.8 & 174.8 & 125.8 & 48.2 & 135.2 & 176.6 & 129.8 & 51.9 & 122.5 & 162.3 & 117.8 & 39.3 \\
\hline
\end{tabular}

Source: Self-authorship.

Each histogram value of each ceramic shown in Table 3 is the average value obtained from six data points, whose standard deviation (of each data gathering) has values between 0.1 and 2.97.

\section{Discussion}

Lists the parameters obtained in the characterization of the ceramic with the chromatic variation produced by applying each water repellent product in order to verify the degree of influence of the parameters obtained with this color variation.

It is presented in table 4, of each ceramic, the chromatic differences between their initial and final color. (Coronado, 2012) states that variations of RGB or luminosity in more than two units, are perceptible by the human eye. 
Table 4. Difference between initial and final color.

\begin{tabular}{|c|c|c|c|c|c|c|c|c|c|c|c|c|}
\hline \multirow[b]{3}{*}{ Ceramic } & \multicolumn{12}{|c|}{ Difference between initial and final color (between parenthesis indicates $\%$ variation in absolute value) } \\
\hline & \multicolumn{4}{|c|}{ H1 Siliconates } & \multicolumn{4}{|c|}{$\mathrm{H} 2$ Silanes } & \multicolumn{4}{|c|}{ H3 Oligomeric Siloxanes } \\
\hline & Lumin. & Red & Green & Blue & Lumin. & Red & Green & Blue & Lumin. & Red & Green & Blue \\
\hline \multirow[t]{2}{*}{1} & 6.3 & 4.0 & 3.3 & 7.0 & 7.9 & 5.2 & 4.7 & 10.7 & 7.9 & 3.9 & 5.0 & 12.4 \\
\hline & $(2.5)$ & (1.6) & $(1.3)$ & $(2.8)$ & (3.1) & (2.0) & (1.8) & (4.2) & (3.1) & (1.5) & (2.0) & (4.9) \\
\hline \multirow[t]{2}{*}{2} & 8.0 & 1.6 & 9.0 & 13.7 & 9.2 & 6.2 & 8.5 & 15.7 & 7.5 & 3.0 & 7.6 & 13.6 \\
\hline & (3.1) & $(0.6)$ & (3.5) & (5.4) & (3.6) & (2.4) & (3.4) & (6.1) & (2.9) & $(1.2)$ & (3.0) & $(5,3)$ \\
\hline \multirow[t]{2}{*}{3} & -2.3 & -2.6 & -0.6 & -0.2 & -4.3 & -4.8 & -2.4 & -3.3 & 0.0 & -1.2 & 2.0 & 3.0 \\
\hline & $(0.9)$ & $(1.0)$ & $(0.2)$ & $(0.1)$ & (1.7) & (1.9) & (1.0) & (1.3) & $(0.0)$ & $(0.5)$ & $(0.8)$ & (1.2) \\
\hline \multirow[t]{2}{*}{4} & 16.1 & 13.2 & 15.6 & 14.3 & 5.7 & 4.2 & 4.8 & 2.6 & 9.1 & 7.8 & 7.5 & 9.4 \\
\hline & (6.3) & $(5.2)$ & (6.1) & $(5.6)$ & $(2.2)$ & (1.6) & (1.9) & (1.0) & (3.6) & (3.1) & (2.9) & (3.7) \\
\hline \multirow[t]{2}{*}{5} & 7.4 & 5.7 & 6.4 & 10.8 & 8.9 & 6.5 & 7.9 & 15.2 & 8.1 & 5.9 & 7.1 & 12.9 \\
\hline & (2.9) & $(2.2)$ & $(2.5)$ & $(4.2)$ & (3.5) & (2.5) & (3.1) & (5.9) & (3.2) & $(2.3)$ & $(2.8)$ & (5.0) \\
\hline \multirow[t]{2}{*}{6} & 8.0 & 3.7 & 9.1 & 13.0 & 11.7 & 5.5 & 13.0 & 22.2 & 8.9 & 4.9 & 9.7 & 14.8 \\
\hline & (3.1) & $(1.4)$ & (3.6) & (5.1) & (4.6) & (2.1) & $(5.1)$ & (8.7) & (3.5) & (1.9) & (3.8) & (5.8) \\
\hline \multirow[t]{2}{*}{7} & 11.4 & 8.4 & 10.9 & 22.4 & 4.9 & 7.7 & 4.3 & 1.1 & 11.4 & 11.3 & 11.1 & 22.4 \\
\hline & $(4.5)$ & (3.3) & $(4.3)$ & (8.8) & (1.9) & (3.0) & (1.7) & $(0.4)$ & $(4.5)$ & $(4.4)$ & $(4.4)$ & (8.8) \\
\hline \multirow[t]{2}{*}{8} & 6.1 & 3.0 & 6.3 & 14.2 & 7.4 & 4.2 & 7.6 & 14.9 & 9.8 & 6.3 & 10.7 & 14.8 \\
\hline & $(2.4)$ & $(1,2)$ & $(2.5)$ & $(5.5)$ & (2.9) & (1.6) & (3.0) & (5.8) & (3.9) & $(2.5)$ & (4.2) & (5.8) \\
\hline \multirow[t]{2}{*}{9} & -15.1 & -18.7 & -13.7 & -13.0 & -2.2 & -6.0 & -1.0 & 1.5 & -1.5 & 1.0 & -2.2 & -4.5 \\
\hline & (5.9) & (7.3) & $(5.4)$ & (5.1) & $(0.9)$ & (2.3) & $(0.4)$ & $(0.6)$ & $(0.6)$ & $(0.4)$ & $(0.8)$ & (1.8) \\
\hline \multirow[t]{2}{*}{10} & 0.1 & -1.5 & 0.6 & 1.8 & -1.3 & -2.0 & -1.1 & -1.0 & 9.1 & 5.0 & 10.4 & 13.5 \\
\hline & $(0.0)$ & $(0.6)$ & $(0.2)$ & $(0.7)$ & $(0.5)$ & $(0.8)$ & $(0.4)$ & $(0.4)$ & (3.6) & (1.9) & (4.1) & (5.3) \\
\hline \multirow[t]{2}{*}{11} & 4.8 & 5.6 & 4.4 & 5.5 & 7.1 & 7.4 & 6.6 & 9.7 & 6.9 & 7.0 & 6.5 & 9.3 \\
\hline & (1.9) & $(2.2)$ & (1.7) & (2.1) & $(2.8)$ & (2.9) & (2.6) & (3.8) & $(2.7)$ & $(2.7)$ & $(2,6)$ & (3.7) \\
\hline \multirow[t]{2}{*}{12} & -13.2 & -16.7 & -11.5 & -12.2 & -10.4 & -13.2 & -8.8 & -10.6 & 2.7 & 0.6 & 3.6 & 3.7 \\
\hline & $(5.2)$ & (6.6) & $(4.5)$ & (4.8) & (4.1) & (5.2) & (3.5) & (4.2) & (1.1) & $(0.2)$ & (1.4) & (1.5) \\
\hline
\end{tabular}

\begin{tabular}{|c|c|c|c|c|c|c|c|c|c|c|c|c|}
\hline \multirow[b]{3}{*}{ Ceramic } & \multicolumn{12}{|c|}{ Difference between initial and final color (between parenthesis indicates \% variation in absolute value) } \\
\hline & \multicolumn{4}{|c|}{ H4 Polymeric Siloxanes } & \multicolumn{4}{|c|}{ H5 Fluorinated Resin } & \multicolumn{4}{|c|}{ H6 Silanes/Siloxanes } \\
\hline & Lumin. & Red & Green & Blue & Lumin. & Red & Green & Blue & Lumin. & Red & Green & Blue \\
\hline \multirow[t]{2}{*}{1} & 8.2 & 3.1 & 5.5 & 15.0 & 13.0 & 5.7 & 10.7 & 24.2 & 36.1 & 17.1 & 36.8 & 62.5 \\
\hline & $(3.2)$ & $(1.2)$ & $(2.2)$ & (5.9) & $(5.1)$ & $(2.2)$ & $(4.2)$ & $(9.5)$ & (14.1) & $(6.7)$ & (14.4) & $(24.5)$ \\
\hline \multirow[t]{2}{*}{2} & 9.7 & 5.2 & 9.2 & 18.8 & 12.8 & 5.3 & 12.8 & 27.8 & 18.0 & 6.9 & 17.7 & 43.7 \\
\hline & (3.8) & $(2.0)$ & (3.6) & (7.4) & $(5.0)$ & $(2.1)$ & $(5.0)$ & (10.9) & $(7.0)$ & $(2.7)$ & $(7.0)$ & $(17.2)$ \\
\hline \multirow[t]{2}{*}{3} & -4.6 & -4.2 & -3.0 & -3.2 & 2.5 & -1.1 & 4.1 & 14.4 & 3.2 & -1.0 & 4.9 & 16.0 \\
\hline & $(1.8)$ & $(1.7)$ & $(1.2)$ & $(1.2)$ & $(1.0)$ & $(0.4)$ & $(1.6)$ & (5.6) & $(1.2)$ & $(0.4)$ & (1.9) & (6.3) \\
\hline \multirow[t]{2}{*}{4} & 9.5 & 9.0 & 8.2 & 5.3 & 17.7 & 14.0 & 16.3 & 23.9 & 18.8 & 12.5 & 16.0 & 39.6 \\
\hline & (3.7) & (3.5) & $(3.2)$ & (2.1) & $(7.0)$ & (5.5) & (6.4) & $(9.4)$ & $(7.4)$ & (4.9) & (6.3) & (15.5) \\
\hline \multirow[t]{2}{*}{5} & 10.6 & 7.4 & 9.7 & 19.0 & 5.5 & 3.9 & 4.5 & 8.5 & 12.0 & 8.4 & 10.9 & 22.5 \\
\hline & $(4.2)$ & (2.9) & (3.8) & (7.5) & (2.1) & (1.5) & (1.8) & (3.3) & (4.7) & (3.3) & $(4.3)$ & (8.8) \\
\hline \multirow[t]{2}{*}{6} & 13.7 & 6.8 & 15.7 & 21.2 & 10.0 & 3.6 & 10.7 & 23.9 & 17.9 & 3.9 & 18.6 & 52.6 \\
\hline & (5.4) & $(2.7)$ & $(6.2)$ & (8.3) & (3.9) & (1.4) & $(4.2)$ & $(9.4)$ & $(7.0)$ & (1.5) & (7.3) & $(20.6)$ \\
\hline \multirow[t]{2}{*}{7} & 19.2 & 12.1 & 19.3 & 38.2 & 14.4 & 10.7 & 13.6 & 28.9 & 14.9 & 9.9 & 14.0 & 33.3 \\
\hline & (7.5) & $(4.7)$ & $(7.6)$ & (15.0) & (5.6) & $(4.2)$ & (5.3) & (11.3) & (5.8) & (3.9) & (5.5) & $(13.1)$ \\
\hline \multirow[t]{2}{*}{8} & 6.9 & 4,1 & 7.1 & 13.6 & 4.8 & 2.2 & 33.2 & 12.4 & 7.1 & 2.4 & 6.3 & 23.6 \\
\hline & $(2.7)$ & $(1,6)$ & $(2.8)$ & (5.4) & (1.9) & $(0.9)$ & (13.0) & (4.9) & $(2.8)$ & $(0.9)$ & $(2.5)$ & (9.3) \\
\hline \multirow[t]{2}{*}{9} & -6.7 & -2.5 & -8.2 & -9.8 & -0.3 & -9.1 & 2.3 & 10.1 & -1.2 & -13.2 & 1.6 & 16.3 \\
\hline & $(2.6)$ & $(1.0)$ & (3.2) & (3.8) & $(0.1)$ & (3.6) & $(0.9)$ & $(4.0)$ & $(0.5)$ & $(5.2)$ & $(0.6)$ & (6.4) \\
\hline \multirow[t]{2}{*}{10} & 8.3 & 5.5 & 9.3 & 10.4 & 13.6 & 5.2 & 15.5 & 25.6 & 18.6 & 3.2 & 21.8 & 43.0 \\
\hline & (3.2) & $(2.2)$ & (3.6) & (4.1) & (5.3) & $(2.1)$ & (6.1) & (10.0) & (7.3) & (1.3) & (8.5) & (16.9) \\
\hline \multirow[t]{2}{*}{11} & 4.4 & 4.6 & 4.0 & 6.2 & 4.1 & 4.2 & 3.7 & 6.3 & 4.8 & 4.7 & 4.5 & 7.1 \\
\hline & $(1.7)$ & $(1.8)$ & $(1.6)$ & $(2.4)$ & (1.6) & $(1.6)$ & (1.5) & $(2.5)$ & (1.9) & $(1.8)$ & $(1.7)$ & (2.8) \\
\hline \multirow[t]{2}{*}{12} & -2.6 & -9.3 & -0.1 & 1.8 & -6.0 & -11.1 & -4.1 & -1.9 & 6.7 & 3.2 & 7.8 & 10.7 \\
\hline & $(1.0)$ & (3.6) & $(0.0)$ & $(0.7)$ & $(2.4)$ & $(4.4)$ & (1.6) & $(0.7)$ & $(2.6)$ & $(1.2)$ & (3.1) & (4.2) \\
\hline
\end{tabular}

Source: Self-authorship.

To see if there is a relationship between the final color obtained in the waterproofed ceramic and its characteristic values, the results obtained from the values of a histogram are graphed (luminosity, red, green and blue) of each waterproofed ceramic with each of the products, by placing in the horizontal axis (X) each one of the characteristic values of the untreated ceramics in the vertical axis $(\mathrm{Y})$ the color values in the waterproofed ceramic, getting a point cloud. It is estimated the equation of the trend line in the cloud of points obtained and the coefficient of determination $R^{2}$, which tells us if there is a relationship between variables tested. $R^{2}$ values greater than 0.5 indicate that there is a relationship between the variables represented, there is a strong relationship between the variables represented, when the value for $\mathrm{R}^{2}$ is closer to the unit. If there is a relationship between variables, this relationship is defined by the equation of the trend line. 
Figure 3 shows an example of the results obtained from the green color, relating the initial color and the final color obtained with the application in the waterproofed ceramics and siliconate component $(\mathrm{H} 1)$, where the trend line can be observed, its equation and the coefficient $\mathrm{R}^{2}$.

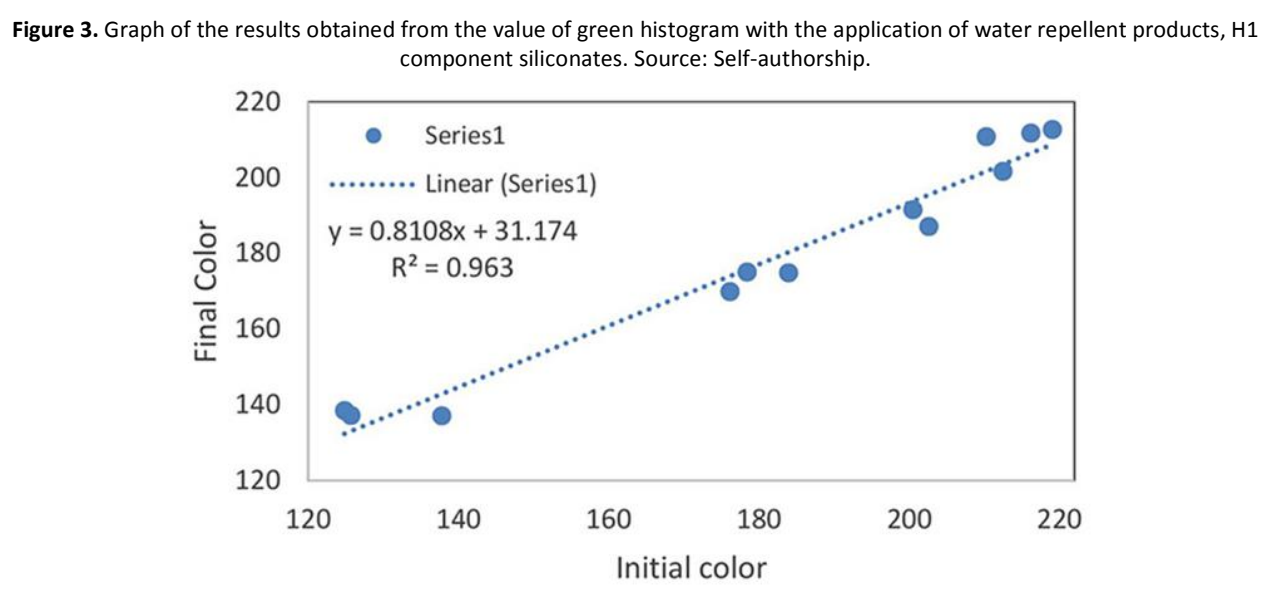

\section{Absorption Coefficient}

The values of the absorption coefficient with the values of a final color histogram of the waterproofed ceramic are related, getting in all the cases of $R^{2}$ values less than 0.22 , there is no relationship between the final color of the ceramic and the absorption coefficient.

Tables 1 and 4 shows that ceramics with very similar absorption coefficients present chromatic differences of a different type and there is no relationship between these parameters.

\section{Open Porosity}

The values obtained from the open porosity, are related to each value of luminosity, red, green, and blue of the final color of the waterproofed ceramic, getting in all the cases of $\mathrm{R}^{2}$ values less than 0.25 , there is no relationship between the final color of the ceramic and the open porosity.

It can be seen in table 1 and 4 that ceramics with open porosity of a similar order, have chromatic variations of different orders of magnitude, and it is visible that between these two variables there is no relationship.

\section{Absorption Rate}

The results obtained from the rate of absorption, before and after waterproofing the ceramic are associated with each value of lightness, red, green, and blue of the final color of the waterproofed ceramic. In all cases the values of $R^{2}$ are lower than 0.15 , there is no relationship between the final color of the ceramic and the rate of absorption.

It can be seen in tables 1,2 and 4 that ceramics before and after being waterproofed with absorption rates of the same order, presented chromatic variations of different magnitude, so between these two variables there is no relationship.

\section{Surface Finishing}

Fort (2011) states that water repellents are treatments that form a continuous film that coats the surface of the pores, without clogging them, so that when applying the water repellents the final texture of the ceramic does not vary substantially. After the application of the water repellents, visual and tactile checks are made, showing that the final finish of the ceramics does not change, maintaining the initial classification reflected in Table 1.

At analyzing Tables 3 and 4, it shows that ceramics with equal surface finishes present a very different chromatic variation, depending on the water repellent product. Ceramics with different surface finishes presented a variation of color of a similar type. There is no relationship between the surface finishing of the ceramics and the color variation that occurs in the ceramics to be waterproofed. 


\section{Initial Color}

Ceramics when is waterproofed, with theoretically colorless products, adopts shades different from the original ones, quantified by the primary colors (red, green and blue) and by their luminosity (Coronado \& García, 2011). In order to identify if there is a relation between the initial and final histogram values, they are represented as shown in Figure 3 , obtaining the values shown in Table 5, of the equations of the trend line and the coefficient of determination $\mathrm{R}^{2}$.

Table 5. Relationship between the values of initial and final histogram depending on the type of water repellent being applied.

\begin{tabular}{|c|c|c|c|c|c|c|}
\hline \multirow{4}{*}{$\begin{array}{l}\text { Histogram } \\
\text { Values } \\
\text { Luminosity }\end{array}$} & \multicolumn{6}{|c|}{ Relationship between initial and final color of the ceramic } \\
\hline & \multicolumn{6}{|c|}{ Type of water repellent product } \\
\hline & \multicolumn{2}{|c|}{ H1 Siliconates } & \multicolumn{2}{|c|}{ H2 Silanes } & \multicolumn{2}{|c|}{ H3 Oligomeric Siloxanes } \\
\hline & $\begin{aligned} y & =0.7698 x \\
& +39.571\end{aligned}$ & $R^{2}=0.9435$ & $\begin{aligned} y & =0.7384 x \\
& +54.035\end{aligned}$ & $R^{2}=0.9654$ & $\begin{aligned} y & =0.9205 x \\
& +12.323\end{aligned}$ & $R^{2}=0.9764$ \\
\hline Red & $\begin{aligned} y & =0.6228 x \\
& +79.92\end{aligned}$ & $R^{2}=0.8659$ & $\begin{array}{c}y=0.7785 x \\
+43.940\end{array}$ & $R^{2}=0.9459$ & $\begin{aligned} y & =0.9154 x \\
& +13.09\end{aligned}$ & $R^{2}=0.9781$ \\
\hline Green & $\begin{array}{c}y=0.8108 x \\
+31.174\end{array}$ & $R^{2}=0.963$ & $\begin{array}{c}y=0.8972 x \\
+15.056\end{array}$ & $R^{2}=0.9775$ & $\begin{array}{c}y=0.9592 x \\
+0.8459\end{array}$ & $R^{2}=0.9881$ \\
\hline Blue & $\begin{array}{c}y=0.8696 x \\
+9.9243\end{array}$ & $R^{2}=0.9518$ & $\begin{array}{c}y=0.9425 x \\
+0.6619\end{array}$ & $R^{2}=0.9565$ & $\begin{array}{c}y=0.9496 x \\
-4.1336\end{array}$ & $R^{2}=0.9777$ \\
\hline \multirow{3}{*}{$\begin{array}{l}\text { Histogram } \\
\text { values }\end{array}$} & \multicolumn{6}{|c|}{ Relationship between initial and final color of the ceramic } \\
\hline & \multicolumn{6}{|c|}{ Type of water repellent product } \\
\hline & \multicolumn{2}{|c|}{ H4 Polymeric Siloxanes } & \multicolumn{2}{|c|}{ H5 Fluorinated Resin } & \multicolumn{2}{|c|}{ H6 Silanes/Siloxanes } \\
\hline Luminosity & $\begin{array}{c}y=0.7899 x \\
+41.313\end{array}$ & $R^{2}=0.9437$ & $\begin{array}{c}y=0.7392 x \\
+52.788\end{array}$ & $R^{2}=0.9204$ & $\begin{aligned} y & =0.8416 x \\
& +28.937\end{aligned}$ & $R^{2}=0.8732$ \\
\hline Red & $\begin{array}{c}y=0.8296 x \\
+31.932\end{array}$ & $R^{2}=0.9529$ & $\begin{aligned} y & =0.8265 x \\
& +32.79\end{aligned}$ & $R^{2}=0.9161$ & $\begin{array}{c}y=0.9621 x \\
+0.0447\end{array}$ & $R^{2}=0.9213$ \\
\hline Green & $\begin{aligned} y & =0.9002 x \\
& +11.79\end{aligned}$ & $R^{2}=0.9561$ & $\begin{array}{c}y=0.9585 x \\
-2.6944\end{array}$ & $R^{2}=0.9273$ & $\begin{array}{c}y=0.9929 x \\
-12.126\end{array}$ & $R^{2}=0.9269$ \\
\hline Blue & $\begin{array}{c}y=0.9068 x \\
+0.3017\end{array}$ & $R^{2}=0.9247$ & $\begin{array}{c}y=0.9702 x \\
-13.27\end{array}$ & $R^{2}=0.9531$ & $\begin{array}{c}y=1.057 x- \\
38.066\end{array}$ & $R^{2}=0.8867$ \\
\hline
\end{tabular}

Source: Self-authorship.

There is a very strong relationship between the values of a histogram of the initial and final color and waterproofed ceramic with the different products, because in all cases, there is a $\mathrm{R}^{2}$ coefficient greater than 0.86 . The relationship between the initial and final color of the waterproofed ceramic is determined by the differential equations that are presented in table 5 .

\section{Conclusions}

According to the research done, it can be concluded that the color variation produced in the ceramic by being waterproofed with theoretically colorless products does not depend on the absorption coefficient (CA), on the open porosity $(\beta)$, on the absorption rate (C), or on the surface finish and only depends on the initial color of the ceramic.

There is a linear relationship, defined by the equations presented in chart $\mathrm{V}$, between the histogram values of the initial and final color of the waterproofed ceramic with each of the applied products. The chromatic variation of the ceramic depends only on the initial color of the ceramics and the water repellent product being applied.

When there is a linear relationship between the initial and final color of a ceramic, it is possible to predict the final color of a ceramic, knowing its initial color, according to their RGB values, depending on the composition of the water repellent product being applied. 
AENOR-CEN (1984). UNE 67027-84. Ladrillos de arcilla cocida. Determinación de la absorción de agua. Asociación Española de Normalización (AENOR).

AENOR-CEN (1999). UNE-EN 772-4. Métodos de ensayo de piezas para fábrica de albañilería. Parte 4: Determinación de la densidad real y aparente y de la porosidad abierta y total de piezas de piedra natural para fábrica de albañilería. Asociación Española de Normalización (AENOR).

AENOR-CEN (2001). UNE-EN 772-11. Métodos de ensayo de piezas para fábrica de albañilería. Parte 11: determinación de la absorción de agua por capilaridad de piezas para fábrica de albañilería, en hormigón, piedra natural y artificial, y de la tasa de absorción de agua inicial de las piezas de arcilla cocida para fábrica de albañilería. Asociación Española de Normalización (AENOR).

Akhan Baykan, N., Yılmaz, N., \& Kansun, G. (2010). Case study in effects of color spaces for mineral identification. Scientific Research and Essays, 5(11), 1243-1253. Retrieved from http://www.academicjournals.org/article/article1381226810_Baykan et al.pdf.

Álvarez de Buergo Ballester, M., \& Fort González, R. (2002). Characterizing the construction materials of a historic building and evaluating possible preservation treatments for restoration purposes. Geological Society, London, Special Publications, 205(1), $241-254$. https://doi.org/https://doi.org/10.1144/GSL.SP.2002.205.01.18

Álvarez de Buergo Ballester, M., \& Fort González, R. (2001). Basic methodology for the assessment and selection of water-repellent treatments applied on carbonatic materials. Progress in Organic Coatings, 43(4), 258-266. https://doi.org/10.1016/50300-9440(01)00204-1

Amoroso, G. G., \& Fassina, V. (1985). Stone Decay and Conservation: Atmospheric Pollution, Cleaning, Consolidation and Protecting. Bulletin of the Association for Preservation Technology, 17(3/4), 84. https://doi.org/10.2307/1494105

Chávez Vega, J. A., \& Álvarez Rodríguez, O. (2014). Metodología para el diagnóstico y restauración de edificaciones. Revista de La Construcción. Journal of Construction, 4(2), 47-54. Retrieved from http://rdlc.alerta.cl/index.php/rdlc/article/view/415

Coronado Martín, J. A. (2012). Influencia de los Productos Hidrofugantes en las Propiedades Superficiales de las Cerámicas Porosas Utilizadas en Cerramientos Exteriores Cara Vista. Universidad Politécnica de Madrid.

Coronado Martin, J. A., \& García Santos, A. (2011). La influencia de los productos hidrofugantes en las modificaciones cromáticas del ladrillo cerámico. Materiales de Construcción, 61(304), 597-611. https://doi.org/doi: http://dx.doi.org/10.3989/mc.2011.57810

Coronado Martín, J. A.; García Santos, A. (2014). Hidrofugante que menor variación cromática produce en la cerámica porosa cara vista. Boletín de La Sociedad Española de Cerámica Y Vidrio, 53(5), i-vi. https://doi.org/DOI: 10.3989 / cyv.2014.v53.i5

Coronado Martín, J. A., García Santos, A., \& Padial Molina, J. F. (2013). La influencia de los productos hidrofugantes en la succión del ladrillo cerámico cara vista. Boletín de La Sociedad Española de Cerámica Y Vidrio, 52(4). https://doi.org/10.3989/cyv.2013.v52.i4.1221

Cultrone, G., Cazalla, O., Rodríguez, C., De la Torre, M. J., \& Sebastián, E. (2005). Técnicas no destructivas aplicadas a la conservación del patrimonio arquitectónico. Colorimetría. Boletín Del Instituto Andaluz Del Patrimonio Histórico, (53), 6-10.

Esbert, R. M., \& Sánchez, J. A. (1995). Hidrofugación de rocas carbonatadas porosas: Propiedades que controlan su eficacia Waterproofing of porous carbonate rocks: Efficiency- controlling its properties. Materiales de Construcción, 45(237), 15-30. Retrieved from http://digital.csic.es/bitstream/10261/88513/1/12-12-2013.pdf

Fort González, R., Pérez-Monserrat, E. M., Layuno Rosas, M. de los Á., Varas, M. J., Álvarez de Buergo, M., Martínez-Ramírez, S., ... Undurraga Letelier, R. (2012). La conservación de los geomateriales utilizados en el patrimonio. Universidad Complutense de Madrid. Retrieved from http://hdl.handle.net/10261/46731

Fortes Revilla, C., \& Blanco-Varela, M. (2001). Influence of water-repellent treatment on the properties lime and lime pozzolan mortars. Materiales de Construcción, 5(262), 39-52.

García Pascua, N., Sánchez de Rojas, M. I., \& Frías, M. (1999). Medidas de color en diferentes materiales de construcción. La restauración en edificios de arenisca. Materiales de Construcción, 49(253), 29-45.

García Santos, A. (2001). Los Plásticos en la Construcción I y II. Madrid. Madrid. Cuadernos del Instituto Juan Herrera, Escuela Técnica Superior de Arquitectura

García Santos, A., \& Conci Rinaudo, M. (2005). Variación del color del soporte cerámico tratado con pintura antigraffiti. Materiales de Construcción, 55(278), 55-68. https://doi.org/10.3989/mc.2005.v55.i278.189

Heathcote, K. A. (1995). Durability of earthwall buildings. Construction and Building Materials, 9(3), 185-189. https://doi.org/10.1016/09500618(95)00035-E

Pérez-Monserrat, E. M., Gómez-Heras, M., Álvarez de Buergo, M., \& Fort González, R. (2007). Ciencia, tecnología y sociedad: para una conservación sostenible del patrimonio pétreo. Restauradores Sin Fronteras. Retrieved from http://hdl.handle.net/10261/7981

Rivas, T., Silva, B., \& Prieto, B. (1998). Medida de la durabilidad de dos tratamientos de hidrofugación aplicados a rocas graníticas. Materiales de Construcción, 48(250), 5-14. Retrieved from http://materconstrucc.revistas.csic.es/index.php/materconstrucc/article/view/475/523

Sarabia Castelló, E., \& García Santos, A. (2015). Variation of the surface chromatic properties of exposed concrete façades treated with anti-graffiti products. Revista de la Construcción, 15(1), 51-60. Retrieved from http://rdlc.alerta.cl/index.php/rdlc/article/view/593/130

Silva, B., Rivas, T., \& Prieto, B. (2000). Tratamientos de consolidación e hidrofugación aplicados a sustratos graníticos húmedos y contaminados por sales solubles. Materiales de Construcción, 50(257), 15-31. https://doi.org/10.3989/mc.2000.v50.i257.415 
Tsakalof, A., Manoudis, P., Karapanagiotis, I., Chryssoulakis, I., \& Panayiotou, C. (2007). Assessment of synthetic polymeric coatings for the protection and preservation of stone monuments. Journal of Cultural Heritage, 8(1), 69-72. https://doi.org/10.1016/j.culher.2006.06.007

Wacker-chemie, G. (1973). Procedimiento para hidrofugar superficies de materiales de construcción. Invention Patent. 